\title{
PELATIHAN PENYUSUNAN RENCANA PELAKSANAAN PEMBELAJARAN (RPP) BERBASIS KURIKULUM 2013 DI SMP MUHAMMADIYAH 1 PURWOKERTO
}

\author{
Dodi Siraj Muamar Zain ${ }^{1}$, Titi Wahyukti ${ }^{2}$, dan Endang Kusrini ${ }^{3}$ \\ Fakultas Keguruan dan Ilmu Pendidikan, Universitas Muhammadiyah Purwokerto \\ Email : ${ }^{1}$ dodisiraj@ump.ac.id, ${ }^{2}$ titiwahyukti@ump.ac.id, ${ }^{3}$ endangkusrini@ump.ac.id
}

\begin{abstract}
This community service aimed at training teachers of SMP Muhammadiyah 1 Purwokerto in developing lesson plans which are based on the curriculum 2013. During the training, teachers were not only presented the structure of lesson plans yet they got explanation about teaching practices based on the curriculum 2013. They involved the concept of scientific approach and students-centered learning. It is expected that this activity can assist teachers in developing lesson plans and constructing teaching activities based on the applied curriculum.
\end{abstract}

Keywords: Lesson Plan, Curriculum 2013

\section{PENDAHULUAN}

SMP Muhammadiyah I Purwokerto merupakan salah satu SMP swasta yang berada di bawah naungan organisasi Muhammadiyah. Sekolah ini terletak di Jl. Perintis Kemerdekaan No. 6 Purwokerto. Secara keseluruhan, jumlah tenaga pendidik yang dimiliki sekolah ini berjumlah 39 Guru dengan lebih dari 15 guru telah memperoleh sertifikat pendidik. Secara keseluruhan, jumlah siswa yang mengenyam pendidikan di sekolah ini berjumlah 365 siswa.

Dalam perkembangannya, SMP Muhammadiyah I Purwokerto telah banyak menunjukkan eksistensinya di masyarakat melalui prestasi yang ditorehkan. Pihak sekolah senantiasa berbenah diri untuk meningkatkan kualitas baik dari segi pengajaran, manajemen, maupun infrastruktur yang dimiliki. Hal ini terlihat dari pencapaian akreditasi A yang telah ditorehkan oleh sekolah ini yang menunjukkan sejauh mana tingkat kelayakan yang dimiliki sekolah ini dibandingkan dengan sekolah yang lain. Disamping itu, sekolah ini juga telah menjalin kerjasama dengan sekolah di luar negeri melalui program sister school dengan mengirim beberapa siswa untuk belajar dalam periode waktu tertentu dan mendatangkan tenaga pengajar dari Thailand untuk praktik pengajaran di SMP tersebut. 
Di bawah naungan organisasi Muhammadiyah, sekolah ini merupakan salah satu SMP swasta yang memiliki ciri khas keislaman. Ciri keislaman yang sangat jelas terlihat adalah penggunaan busana yang disesuaikan dengan tata cara berbusana islami. Selain itu, pihak sekolah juga mendorong para siswa untuk melaksanakan kegiatan peribadatan dengan baik yang salah satunya terlihat dari kegiatan sholat berjamaah yang dilakukan di sekolah. Hal ini sejalan dengan visi dan misi sekolah dimana sekolah senantiasa berusaha untuk menciptakan generasi muslim yang kuat dalam iman, serta mampu menguasai ilmu pengetahuan dan teknologi untuk untuk mampu bersaing di masa depan.

Kurikulum 2013 dikembangkan oleh pemerintah untuk menjadi acuan dalam praktik kegiatan belajar mengajar di tingkat Pendidikan dasar dan menengah. Bagi sebagian besar institusi negeri, kurikulum ini telah diterapkan secara intensif sejak tahun 2015. Akan tetapi, bagi beberapa institusi swasta, penggunaan kurikulum sebelum kurikulum 2013 yakni kurikulum tingkat satuan Pendidikan (KTSP) masih cukup besar. SMP Muhammadiyah 1 Purwokerto merupakan salah satu instansi pendidikan swasta yang pada tahun ajaran selanjutnya yakni tahun ajaran 2016/2017 baru akan menerapkan kurikulum 2013.

\section{Identifikasi Masalah}

Penerapan kurikulum 2013 bukan tanpa masalah. Guru dituntut untuk bisa menerapakan model pembelajaran yang lebih menekankan pada keikutertaan aktif siswa dalam pembelajaran. Pada dasarnya, prinsip pembelajaran semacam ini memiliki dasar pemikiran yang sama dengan yang dilaksanakan pada penerapan KTSP. Akan tetapi, kurikulum 2013 memberikan penekakan pada pengembangan karakter siswa melalui implementasi penilaian otentik dan pendekatan saintifik.

Model pembelajaran baru dengan basis pendekatan yang berbeda berimbas pada praktik pengajaran yang tertuang dalam penyusunan RPP (Rencana Pelaksanaan Pembelajaran). Hal ini tentu saja memberikan tantangan bagi guruguru khususnya guru SMP Muhammadiyah 1 Purwokerto dalam menyusun RPP sesuai kaidah yang ditetapkan. Dalam hal ini, para guru harus mampu menuangkan kreatifitas mereka untuk mewujudkan suatu model pembelajaran berbasis siswa dengan 
model pendekatan saintifik yang menjadi inti dari kurikulum 2013.

Pada tahun ajaran 2017/2018, SMP Muhammadiyah 1 Purwokerto akan menetapkan kurikulum 2013 dalam proses pembelajaran. Walau secara umum, kurikulum ini telah dikenal luas khususnya oleh pihak SMP Muhammadiyah 1 Purwokerto, namun pada pelaksanaannya dibutuhkan beberapa persiapan baik dari segi administratif maupun praktik pengajaran. Salah satu hal yang menjadi pokok perhatian adalah penyusunan atau pengembangan RPP rencana pelaksanaan pembelajaran.

RPP yag digunakan pada kurikulum 2013 pada dasarnya mirip dengan RPP pada kurikulum sebelumnya namun ada beberapa penggunaan istilah baru seperti kompetensi inti dan pendekatan saintifik. Pemahaman mengenai kompetensi inti sangat penting untuk menyusun indikator dan tujuan pembelajaran. Sedangkan pemahaman mengenai pendekatan saintifik menjadi poin utama dalam penyusunan langkahlangkah pembelajaran.

Kegiatan pelatihan yang diadakan dalam rangka pengabdian pada masyarakat ini menekankan pada pemahaman mengenai prinsip dasar penerapan kurikulum 2013. Hal ini mencakup pendekatan yang berpusat pada siswa yang menjadi inti dari kegiatan pembelajaran. Di samping itu, para peserta juga diberikan penjelasan mengenai pemilihan kompetensi inti dan kompetensi dasar. Kompetensi ini merupakan acuan dalam menentukan indikator dan tujuan pembelajaran. Dalam hal ini, guru-guru diberikan pemahaman mengenai kata kerja operatif untuk menentukan indikator dan tujuan yang sesuai.

Poin yang tidak kalah penting adalah tentang bagaimana menyusun rangkaian kegiatan pembelajaran dengan menerapkan pendekatan saintifik. Pemberian model-model kegiatan dari setiap langkah pembelajaran menjadi pilihan yang digunakan. Peserta nantinya akan diberikan alternatif model pelaksanaa pembelajaran yang diharapkan sesuai dengan tujuan pembelajaran.

\section{Tujuan dan Manfaat}

Tujuan secara umum dari kegiatan Ipteks bagi masyarakat ini adalah memberikan pelatihan kepada guru-guru SMP Muhammadiyah 1 Purwokerto dalam pengembangan RPP berbasis Kurikulum 2013. Dalam 
pelatihan ini, guru-guru akan diarahkan dalam menentukan tujuan, indikator, serta alur kegiatan pembelajaran yang sesuai dengan kurikulum 2013. Secara tidak langsung, kegitan ini juga menekankan metode pengajaran dengan menerapkan pendekatan saintifik,

Manfaat dari kegiatan ini secara langsung adalah guru-guru mampu menyusun RPP yang sesuai dengan kurikulum 2013. Dalam hal ini, penyusunan tujuan dan indikator telah sesuia dengan silabus pembelajaran. Di samping itu, alur dan jenis kegiatan pembelajaran telah sesuai dengan pendekatan kurikulum 2013.

Kegiatan ini juga memiliki manfaat tidak langsung yakni memberikan gambaran mengenai pembelajaran berpusat pada siswa (student-centered learning) yang juga merupakan inti pada penerapan kurikulum 2013. Selanjutnya guru-guru akan mampu merancang rangkaian kegiatan pembelajaran yang lebih variatif dengan lebih menekankan pada keaktifan siswa.

\section{KHALAYAK SASARAN}

Khalayak sasaran dari kegiatan pengabdian ini adalah guru-guru SMP Muhammadiyah 1 Purwokerto. Lokasi pelaksaaan adalah di SMP Muhammadiyah 1 Purwokerto, Jl. Perintis Kemerdekaan No. 6 Purwokerto. Rangkaian kegiatan IbM ini sendiri dimulai dari persiapan yang dilakukan bulan April dan pelaksanaan pada hari Jumat, 14 Juli 2017.

\section{METODE}

Metode yang digunakan adalah melalui pelatihan pengembangan RPP berbasis kurikulum 2013. Materi pelatihan diarahkan pada pengenalan prinsip dasar kurikulum 2013 yang menekankan pada Pendidikan karakter dan pembelajaran berbasis siswa. Disamping itu, peserta juga diarahkan bagaimana menentukan tujuan pembelajaran sesuai dengan kompetensi yang dipilih dari silabus. setelah diperoleh pemahaman mengenai kurikulum 2013, para peserta kemudian mencoba menyusun RPP berbasis kurikulum 2013.

Langkah-langkah penyelesaian masalah yang digunakan dalam kegiatan pengabdian ini adalah sebagai berikut:

1. Introduction (Pembuka)

Pada tahap ini, Penjelasan awal prinsip pembelajaran berbasis kurikulum 2013. Penyaji menampilkan beberapa slide 


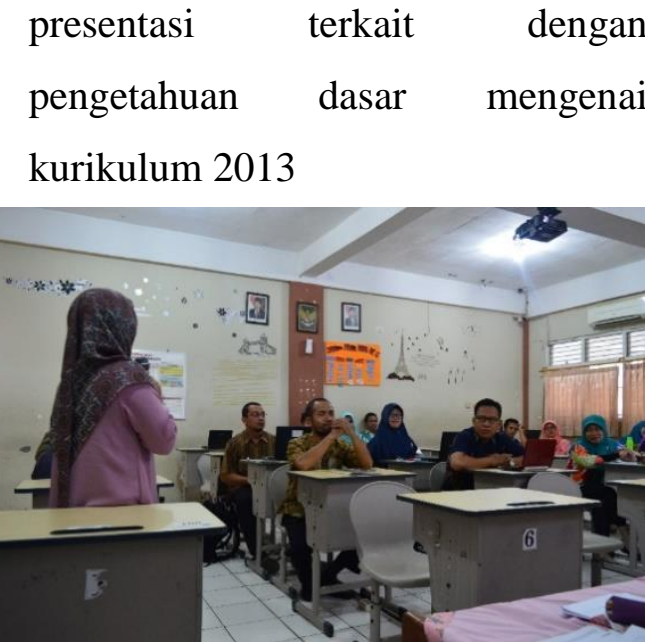

Gambar I.1. Peserta memperhatikan pemaparan penyaji

Pada tahap ini, pendekatan saintifik yang di dalamnya memuat langkahlangkah pembelajaran serta jenisjenis kegiatan yang merefleksikan langkah penerapan tersebut diulas dengan seksama. penyaji juga menyoroti prinsip pembelajaran berbasis siswa dengan memberikan gambaran umum kegiatan pembelajaran yang sejalan dengan pendekatan tersebut.

\section{Presentation}

Setelah memahami konsep dasar dari kurikulum 2013 dan bentuk model pembelajaran yang ada di dalamnya, tahap selanjutnya dari kegiatan ini adalah tahap Presentation. Tahap ini menitikberatkan pada penjelasan mengenai bagaimana cara penyusunan RPP (rencana pelaksanaan pembelajaran).

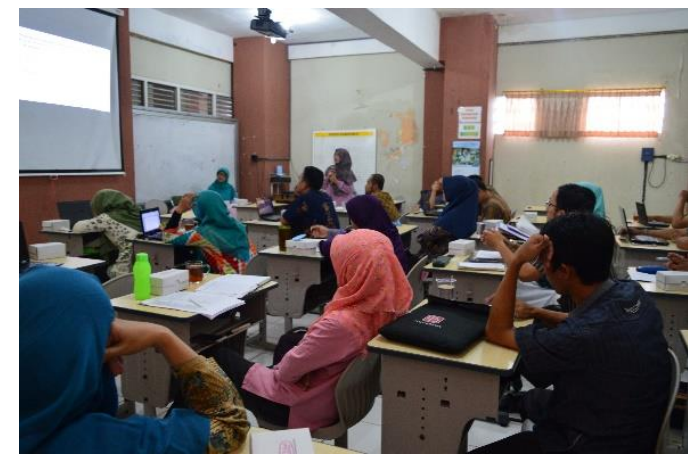

Gambar I.2. Pemaparan penyaji mengenai penyusunan RPP berbasis kurikulum 2013

berisi penjelaskan bagian-bagian RPP serta bagaimana menetukan tujuan dan indicator pembelajaran yang sesuai dengan komptensi inti dan kompetensi dasar. Pemaparan dimmulai dari pemilihan kompetensi inti dan kompetensi dasar. Selanjutnya, penyaji memberikan penjelasan mengenai bagaimana menyusun tujuan dan indicator pembelajaran dari kompetensi tersebut. tahap selanjutanya adalah pemaparan mengeani jenis kegiatan sesai dengan langkah pembalajaran pada pendekatan saintifik dan pendekatan student-centered learning. Tahap terakhir adalah merencanakan jenis evaluasi yang sesuai dengan tujuan pembelajaran. 
Pada kegiatan tanya jawab, ditemukan bahwa beberapa guru telah memiliki pemahaman yang cukup baik mengenai kurikulum 2013. Guru tersebut telah tergabung dalam asosiasi guru atau MGMP (Musyawarah Guru Mata Pelajaran) dan telah memiliki acuan khusus dalam penyususnan RPP. Disamping itu, masih terdapat beberapa guru yang masih mengalami kesulitan dalam pembuatan RPP khususnya bagi yang belum tergabung dalam asosiasi guru.

\section{Workshop}

Pada tahap ini, guru diarahkan untuk menyusun RPP sesuai dengan mata pelajaran yang diampu. Workshop dilakukan dengan membagi guru menjadi beberapa kelompok sesuai dengan mata pelajaran yang diampu. Guru yang telah menyususn RPP berbasis kurikulum 2013 sebelumnya akan diminta untuk membimbing yang lain.

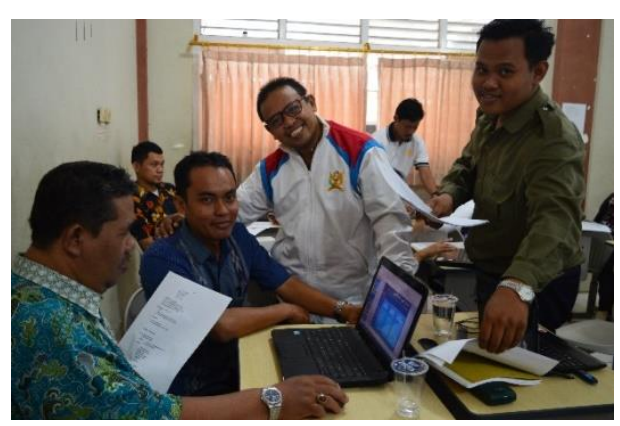

Gambar I.3. Guru bekerja

dalam kelompok menyusun RPP

Pada tahap ini, Penyaji, melakukan pengecekan dan melaksanakan kegiatan tanya jawab dengan kelompok peserta selama tahap ini berlangsung. ditemukan bahwa RPP yang telah disusun sebelumnya masih terdapat ketidaksesuaian antara jenis kegiatan dengan tujuan pembelajaran sehingga diperlukan revisi dari kegiatan tersebut. peserta juga masih kesulitan dalam memilih kata kerja operasional dalam menentukan tujuan pembelajaran serta aktivitas pembelajaran..

\section{Conclusion}

Tahap akhir pada kegiatan ini adalah tahap menyimpulkan. Pada tahap ini, team pelaksana dan peserta akan menarik kesimpulan mengenai apa yang telah dikerjakan. Tahap ini menjadi penutup rangkaian kegiatan pengabdian di SMP MUhammdiyah 1 Purwokerto. 
HASIL

Kegiatan ini dilaksanakan pada tanggal 14 Juli 2017 yang melibatkan 26 Guru di SMP Muhammadiyah 1 Purwokerto. Secara keseluruhan, kegiatan ini berjalan lancar mengingat tahap-tahapan kegiatan bisa dilaksanakan tanpa ada kendala. hal ini tentu saja memberi nilai positif pada diri guru dimana mereka akan terbantu dalam penyusunan RPP berbasis kurikulum 2013.

Dari pelaksanaan kegiatan ini, diperoleh hasil yang sesuai dengan target luaran kegiatan. Dalam hal ini, peserta kegiatan mampu menyusun RPP berbasis kurikulum 2013 sesuai dengan silabus yang telah ditetapkan. Disamping itu, mereka juga memperoleh pemahaman mengenai model pembelajaran berbasis pendekatan saintifik dan pembelajaran yang berpusat pada siswa (studentscentered learning).

\section{KESIMPULAN}

Kegiatan pelatihan ini ditujukan untuk membantu guru guru SMP Muhammadiyah 1 Purwokerto dalam menyusun RPP berbasis kurikulum 2013. Luaran dalam kegiatan ini adalah RPP berbasis kurikulum 2013 yang telah dikembangkan oleh guru-guru. Dengan adanya pelatihan ini, guru juga akan terbantu dalam menyusun kegiatan pembelajaran. Guru secara tidak langsung mendapatkan gambaran mengenai model pembelajaran yang berbasis kepada siswa (students-centered learning) dan pendekatan saintifik.

\section{SARAN}

Dari kegiatan pengabdian ini, diketahui bahwa beberapa guru masih mengalami kesulitan dalam implementasi kurikulum 2013. Oleh karena itu, pelatihan serupa bisa dilaksanakan khususnya pada sekolah yang baru akan menerapkan kurikulum tersebut. disamping itu, kegiatan dengan cakupan penerapan kurikulum 2013 terkait proses evaluasi bisa dilaksanakan mengingat perbedaan sistem evaluasi dibandingkan pada penerapan kurikulum sebelumnya.

\section{DAFTAR PUSTAKA}

Nasution, S. 1989. Kurikulum dan Pengajaran. Bandung: Bumi Aksara.

Poerwati, L.E. \& Amri, Sofan. 2013. Panduan Memahami Kurikulum 2013. Jakarta: Prestasi Pustaka. 